\title{
TREATMENT OF NEPHROSIS WITH CORTISONE 1,2
}

\author{
By JOHN A. LUETSCHER, JR., AND QUENTIN B. DEMING with THE ASSISTANCE or \\ JULIA HARVEY, WILLIAM LEW, AND LEE J. POO
}

(From the Department of Medicine, Stanford University School of Medicine, San Francisco)

(Submitted for publication July 13, 1950; accepted, September 5, 1950)

Cortisone has been given to 11 patients with the nephrotic syndrome. The evaluation of its effect on the renal lesion will require a longer period of study, but some observations on the various manifestations of the nephrotic syndrome are presented here.

Two of the chief manifestations of the nephrotic syndrome are edema and proteinuria. The edema is related to the failure of the patient with nephrosis to excrete sodium in a normal manner. An important factor in this failure appears to be the excessive reabsorption of sodium in the renal tubule (1), suggestive of increased adrenal cortical secretion of a desoxycorticosterone-like substance. An effort has been made to correlate the effects of cortisone with the sodium-retaining activity of the urinary corticoids (2). This method of bioassay has been used in preference to the conventional indices of adrenal function because study was focused on the excretion of sodium. Since the various adrenal steroids may either increase or decrease sodium excretion, determination of total corticoids by reducing power or formaldehyde formation would be meaningless in terms of sodium excretion. Excretion of 17ketosteroids during cortisone therapy would be even more difficult to interpret in terms of effects on sodium excretion. It is recognized that urinary excretion of any adrenal cortical secretion is not an infallible index of circulating level or of physiological activity, but the correlation with clinical changes reported here is strongly suggestive of such a relationship.

Experimental proteinuria is aggravated by several adrenal steroids and is reduced after adrenalectomy $(3,4)$. It seemed possible, therefore, that a reduction of adrenal cortical activity following cortisone administration (5) might have a beneficial

\footnotetext{
1 A report of this work was presented at the 42nd Annual Meeting of the American Society for Clinical Investigation, Atlantic City, May 1, 1950.

2 This investigation was supported by a research grant from the National Heart Institute.
}

effect on the two chief manifestations of the nephrotic syndrome. Furthermore, cortisone shows little sodium-retaining activity in most patients $(6-8)$. Cortisone was used in preference to pituitary adrenocorticotrophin because cortisone is a pure substance whose action is independent of the activity of the patient's adrenal. At the time of this study, some preparations of ACTH were contaminated with posterior pituitary antidiuretic factor, which would have interfered with the interpretation both of initial water retention and of subsequent diuresis (8-11).

\section{PLAN OF TREATMENT AND STUDY}

Eleven patients with characteristic features of the nephrotic syndrome have been treated. No patient with hypertension or renal insufficiency was included in this group. All patients were at bed rest or limited activity in the hospital.

They received an approximately constant diet of limited sodium content, as close as possible to that which they had been taking before admission (10 to 80 m.eq. $\mathrm{Na}$ per day). When the weight was constant or slowly rising for three consecutive days, treatment with cortisone was begun.

Children received a daily total of $100 \mathrm{mg}$. of cortisone acetate in suspension, divided into four doses. Adults were given 100 to $300 \mathrm{mg}$./day as indicated to reduce the eosinophil count below 100 cells per c.mm. Treatment was continued for five to 16 days.

Daily measurements were made of the following quantities: total white blood cell and eosinophil count (12), body weight, intake of fluid and food (calories, nitrogen, sodium, potassium calculated) and urinary output of water, creatinine (13), sodium, potassium, and protein. Blood was drawn approximately every third day for hematocrit, sedimentation rate, and serum sodium, potassium, creatinine, total protein and albumin, and cholesterol. Quantitative examination of the urinary sediment was made before and after treatment. Endogenous creatinine clearance was calculated and corrected for surface area to a standard of $1.73 \mathrm{~m}^{2}$.

The sodium-retaining activity of the urinary corticoids was measured by bioassay in groups of nine adrenalectomized rats (2). The earlier method has been modified by rotation of subgroups, so that all rats do not receive the same test material on the same day, and by the use of a standard dose of $5 \boldsymbol{\gamma}$ of desoxycorticosterone acetate, 
as suggested by Dr. A. G. Spencer (14). The result is expressed as the number of micrograms of DOCA equivalent to an extract of 20 minutes' urine from the patient. Normals and a variety of non-edematous hospital patients have shown a range of 0 to $2.3 \gamma$, averaging $1.4 \gamma$. Changes in urine volume per se do not appear to affect the results of the assay in any consistent fashion.

\section{RESULTS}

Edema, as judged by inspection, was often slightly increased during treatment with cortisone. Body weight increased at most by $3 \mathrm{~kg}$. during treatment, while the average gain was $0.9 \mathrm{~kg}$. at the peak, falling to $0.3 \mathrm{~kg}$. by the end of treatment. After treatment with cortisone, six of the $10 \mathrm{pa-}$ tients had a diuresis with complete elimination of edema (Table I). The changes can best be described by following the urinary excretion of sodium and water (Figures 1-3, Table II).

Urine volume showed no consistent change during administration of cortisone, sometimes decreasing during the early days of treatment, but rising slightly after five days on cortisone. When cortisone was discontinued, there was a steady rise in urine volume, and body weight began to fall on about the third day in those cases in which edema was eliminated. At the end of diuresis, the urine volume was maintained at a level often higher than that during the control period.

Sodium excretion in the urine during treatment was appreciably lower than control values in four cases. Two patients showed small increases in urinary sodium after nine and 14 days of treatment, respectively.

When cortisone was discontinued, there was a steady rise in urinary sodium in six of the patients. Sodium excretion rose to a peak simultaneously with the urine volume, and continued at a high level until edema was eliminated.

Serum sodium concentration fell by an average of $3 \mathrm{~m} . e q . / \mathrm{L}$. during cortisone treatment in the 10 cases in which it was measured, but this decrease was variable and sometimes transitory. Two patients showed a subsequent rise in serum sodium concentration following an increase in urine volume and some loss of weight during the second week of treatment (cases 2 and 1.1). In case 2, a small

TABLE I

Changes in body weight and in proteins after administration of cortisone

\begin{tabular}{|c|c|c|c|c|c|c|c|c|c|c|c|c|c|c|c|c|}
\hline \multirow{2}{*}{$\begin{array}{l}\text { Case } \\
\text { No. }\end{array}$} & \multicolumn{2}{|c|}{ Cortisone } & \multicolumn{2}{|c|}{ Body weight } & \multicolumn{3}{|c|}{ Proteinuria } & \multicolumn{3}{|c|}{ Serum proteins } & \multicolumn{3}{|c|}{ Serum albumin } & \multicolumn{3}{|c|}{ Serum globulin } \\
\hline & $\underset{\mathbf{R x}}{\text { Days }}$ & Total & $\underset{\mathbf{R x}}{\text { After }}$ & $\begin{array}{l}\text { Weight } \\
\text { change }\end{array}$ & Control & $\begin{array}{l}\text { Max. } \\
\text { on } \mathbf{R x}\end{array}$ & $\begin{array}{l}\text { Mini- } \\
\text { mum }\end{array}$ & Control & $\underset{\mathbf{R x}}{\text { End }}$ & $\begin{array}{l}\text { Maxi- } \\
\text { mum }\end{array}$ & Control & $\begin{array}{l}\text { End } \\
\text { Rx }\end{array}$ & $\begin{array}{l}\text { Maxi- } \\
\text { mum }\end{array}$ & Control & $\underset{\mathbf{R x}}{\text { End }}$ & $\underset{\text { mum }}{\text { Maxi- }}$ \\
\hline $\begin{array}{l}1 \\
2 \\
3 \\
4 \\
5 \\
6\end{array}$ & $\begin{array}{r}5 \\
9 \\
8 \\
8 \\
16 \\
8\end{array}$ & $\begin{array}{r}\text { mg. } \\
500 \\
850 \\
925 \\
650 \\
2,100 \\
675\end{array}$ & $\begin{array}{l}\text { kg. } \\
20.0 \\
22.7 \\
49.0 \\
14.8 \\
60.8 \\
16.8\end{array}$ & $\begin{aligned} & \mathrm{kg} . \\
&- 1.0 \\
&-10.0 \\
&-\quad 1.0 \\
&-3.5 \\
&-5.8 \\
&-7.0\end{aligned}$ & \begin{tabular}{|c|}
$g m . / d a y$ \\
1.5 \\
3.6 \\
5.0 \\
3.0 \\
8.9 \\
3.5
\end{tabular} & \begin{tabular}{|c|}
$g m . / d a y$ \\
3.5 \\
4.8 \\
8.7 \\
6.3 \\
12.9 \\
5.4
\end{tabular} & \begin{tabular}{|c|}
$g m . /$ day \\
0.04 \\
0.19 \\
3.9 \\
0.5 \\
8.9 \\
0.5
\end{tabular} & \begin{tabular}{|c|}
$g m . /$ \\
100 cc. \\
4.0 \\
3.9 \\
3.7 \\
3.1 \\
$\overline{3.4}$
\end{tabular} & $\begin{array}{c}g m . / \\
100 \text { cc. } \\
3.7 \\
4.3 \\
4.1 \\
3.7 \\
\frac{3.3}{3.3}\end{array}$ & \begin{tabular}{|c}
$g m . /$ \\
$100 . c$. \\
5.6 \\
5.8 \\
4.1 \\
4.6 \\
$\frac{4.3}{4}$
\end{tabular} & $\begin{array}{c}g m . / \\
100 c c . \\
1.7 \\
1.3 \\
1.5 \\
1.2 \\
1.2\end{array}$ & $\begin{array}{c}g m . / \\
100 c c . \\
1.8 \\
1.8 \\
1.9 \\
1.5 \\
1.5\end{array}$ & $\begin{array}{c}g m . / \\
100 c c . \\
3.3 \\
2.8 \\
2.1 \\
2.5 \\
-\overline{2.1}\end{array}$ & \begin{tabular}{|c|}
$g m . /$ \\
$100 \mathrm{cc.}$ \\
2.3 \\
2.6 \\
2.2 \\
1.9 \\
$\frac{2.2}{2.2}$
\end{tabular} & $\begin{array}{c}g m . / \\
100 c c . \\
1.9 \\
2.5 \\
2.2 \\
2.2 \\
\overline{1.8}\end{array}$ & $\begin{array}{c}\mathrm{gm.l} \\
100 \mathrm{cc} . \\
2.3 \\
3.0 \\
2.0 \\
2.1 \\
\frac{2.2}{2.2}\end{array}$ \\
\hline
\end{tabular}

After administration of cortisone followed by concentrated human serum albumin

\begin{tabular}{|c|c|c|c|c|c|c|c|c|c|c|c|c|c|c|c|c|}
\hline \multirow{2}{*}{7} & 5 & 640 & \multirow[b]{2}{*}{16.8} & \multirow{2}{*}{$\begin{array}{l}+0.4 \\
-2.3 \\
\end{array}$} & \multirow[t]{2}{*}{6.5} & \multirow{2}{*}{$\begin{array}{r}6.6 \\
22.3\end{array}$} & \multirow[t]{2}{*}{4.4} & \multirow[t]{2}{*}{3.4} & \multirow[t]{2}{*}{4.3} & \multirow{2}{*}{$\begin{array}{l}4.2 \\
4.1\end{array}$} & \multirow[t]{2}{*}{1.1} & \multirow[t]{2}{*}{1.6} & \multirow{2}{*}{$\begin{array}{l}1.7 \\
2.3\end{array}$} & \multirow[t]{2}{*}{2.3} & \multirow[t]{2}{*}{2.7} & \multirow{2}{*}{$\begin{array}{l}2.5 \\
1.8 \\
\end{array}$} \\
\hline & \multicolumn{2}{|c|}{ after albumin } & & & & & & & & & & & & & & \\
\hline \multirow{2}{*}{8} & 5 & 1,150 & \multirow[b]{2}{*}{52.6} & \multirow{2}{*}{$\begin{array}{r}+0.8 \\
-15.9\end{array}$} & \multirow[t]{2}{*}{13.5} & 14.2 & \multirow[t]{2}{*}{13.1} & \multirow[t]{2}{*}{4.0} & \multirow[t]{2}{*}{3.9} & 3.7 & \multirow[t]{2}{*}{1.5} & \multirow[t]{2}{*}{1.5} & 1.6 & \multirow[t]{2}{*}{2.5} & \multirow[t]{2}{*}{2.4} & 2.1 \\
\hline & \multicolumn{2}{|c|}{ after albumin } & & & & 34.6 & & & & 4.5 & & & 2.8 & & & 1.7 \\
\hline \multirow{2}{*}{9} & 7 & 670 & \multirow[b]{2}{*}{13.2} & -0.3 & \multirow[t]{2}{*}{2.2} & 3.2 & \multirow[t]{2}{*}{1.3} & \multirow[t]{2}{*}{2.7} & \multirow[t]{2}{*}{3.4} & 3.4 & \multirow[t]{2}{*}{0.9} & \multirow[t]{2}{*}{1.6} & 1.4 & 1.8 & 1.8 & 2.0 \\
\hline & after & bumin & & -0.5 & & - & & & & - & & & - & & & - \\
\hline 10 & 11 & 1,100 & & +0.9 & 4.2 & 7.1 & 6.2 & 3.2 & 3.8 & 3.8 & 1.5 & 2.1 & 2.1 & 1.7 & 1.7 & 1.7 \\
\hline & after & bumin & 12.3 & -3.8 & & 32.0 & & & & 4.9 & & & 3.6 & & & 1.3 \\
\hline 11 & 11 & 1,300 & & 0 & 9.4 & 12.6 & 9.1 & 4.1 & 3.9 & 3.9 & 2.0 & 1.8 & 2.0 & 2.1 & 2.1 & 1.9 \\
\hline & after & bumin & 61.3 & +0.7 & & 40.0 & & & & & & & & & & \\
\hline
\end{tabular}


increase in urinary sodium excretion appeared at the same time.

During the diuresis, after the end of treatment, there was a rise in the serum sodium concentration, which reached a level between 139 and 144 m.eq./L. by the end of the diuresis. In the cases who failed to show a diuresis, the serum sodium rose only slightly after the end of treatment. When albumin was given subsequently, the serum sodium concentration rose by an average of 7 m.eq./L.

Excretion of sodium-retaining corticoids at an abnormally high level was observed in seven of the 10 edematous patients whose urine was assayed. The remaining three patients were at the upper limits of normal. When large changes were observed in the excretion of sodium-retaining corticoids, they were reflected by parallel changes in sodium retention and edema (Table II). In three cases in whom diuresis followed cortisone administration, there was a distinct reduction in the excretion of sodium-retaining corticoids during the diuresis. In three cases, the level of sodiumretaining corticoids was not depressed after the administration of cortisone, and edema was not eliminated. In one case (Figure 3) increased sodium-retaining activity and reaccumulation of some edema was observed when a diuresis was followed by an infection and some reaccumulation of edema.

Endogenous creatinine clearance has been followed as a measure of change in renal function (Table II). In two cases, the endogenous creatinine clearance has been checked by inulin clearances, with similar results.

The serum creatinine concentration fell during or after treatment in three of the 10 patients studied. This change reflected both an improvement in renal function and a decrease in the daily excretion (and presumably in the daily production) of creatinine which occurred in these three patients.

Although the average control creatinine clearance was higher $(60 \mathrm{cc} . / \mathrm{min}$.) in those patients who improved after cortisone than in those who did not (average $48 \mathrm{cc} . / \mathrm{min}$.), the range of 31 to $72 \mathrm{cc}$./min. was identical in the two groups. After treatment, the creatinine clearance increased by 1

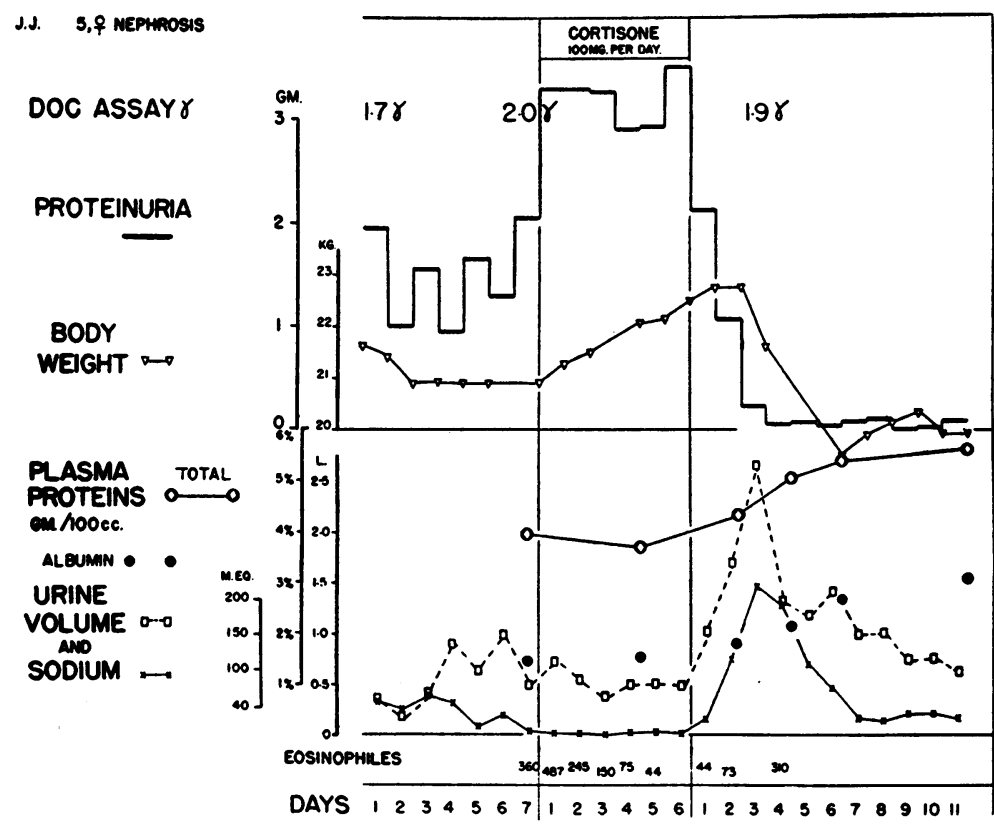

Fig. 1. Temporary Remission following Administration of Cortisone (CAsE 1)

Note the increased proteinuria, diminished sodium excretion, and rise in weight during administration, followed after therapy by cessation of proteinuria, diuresis, and return of serum protein and albumin concentration to virtually normal levels. Edema recurred two weeks later. 


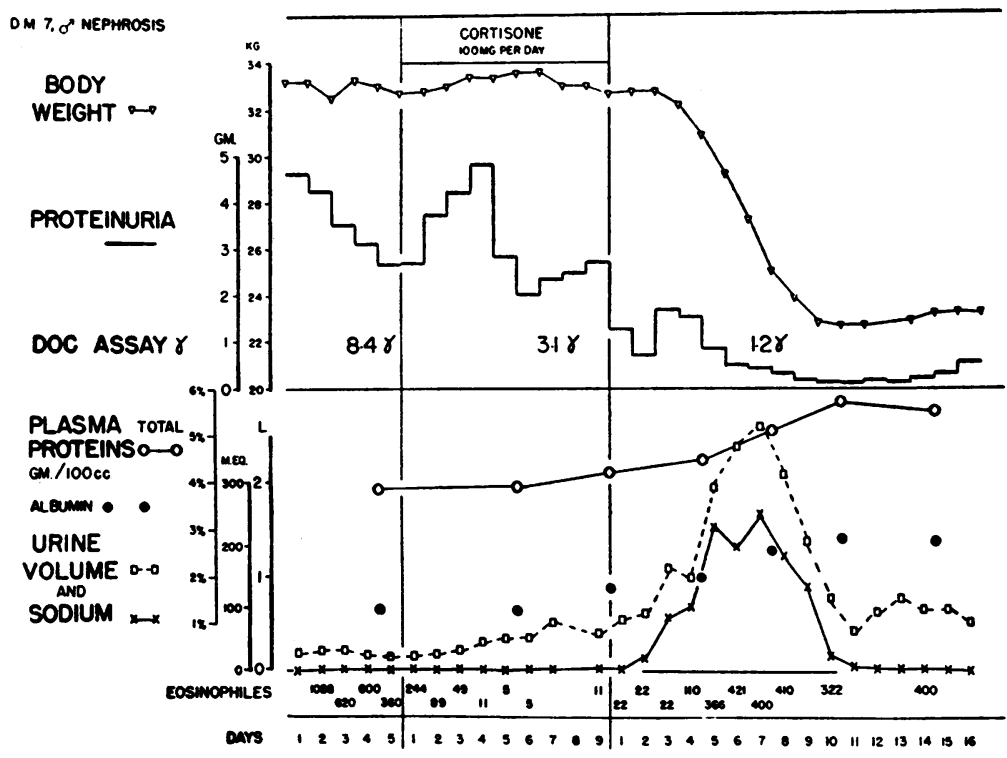

Fig. 2. Prolonged Clinical Remission Following Administration of Cortisone (CASE 2)

Note temporary rise in proteinuria and weight during therapy, with some improvement after the fourth day of therapy, followed after end of treatment by elimination of over $10 \mathrm{~kg}$. of edema, reduction of proteinuria to less than $0.5 \mathrm{gm}$. per day, and an increase in serum protein and albumin concentration approaching normal levels. Assay of sodium-retaining corticoids fell to normal levels after treatment. Clinical improvement has been maintained for four months.

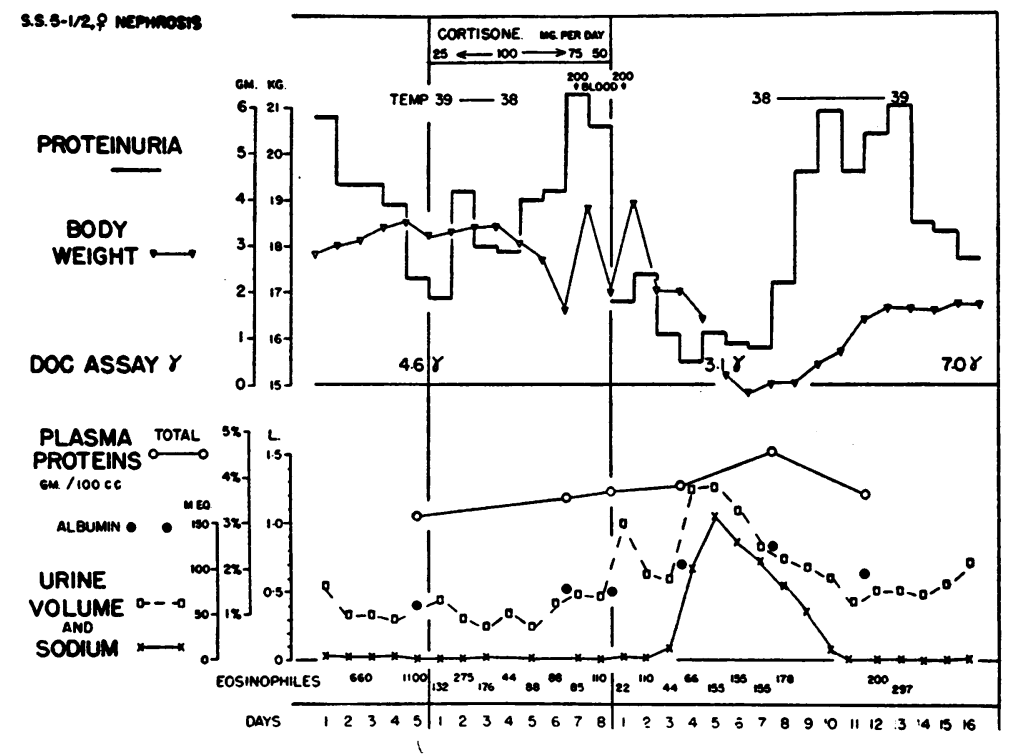

Fig. 3. Brief Remission Interrupted by Infection (CASE 4)

Note the rising serum protein and albumin concentrations during therapy, the different protein loss from equal transfusions during and after cortisone administration, and the rise in sodium-retaining corticoids (DOC assay) with relapse. This patient subsequently lost the edema regained during infection, and has been free of edema for three months. 
JOHN A. LUETSCHER, JR., AND QUENTIN B. DEMING

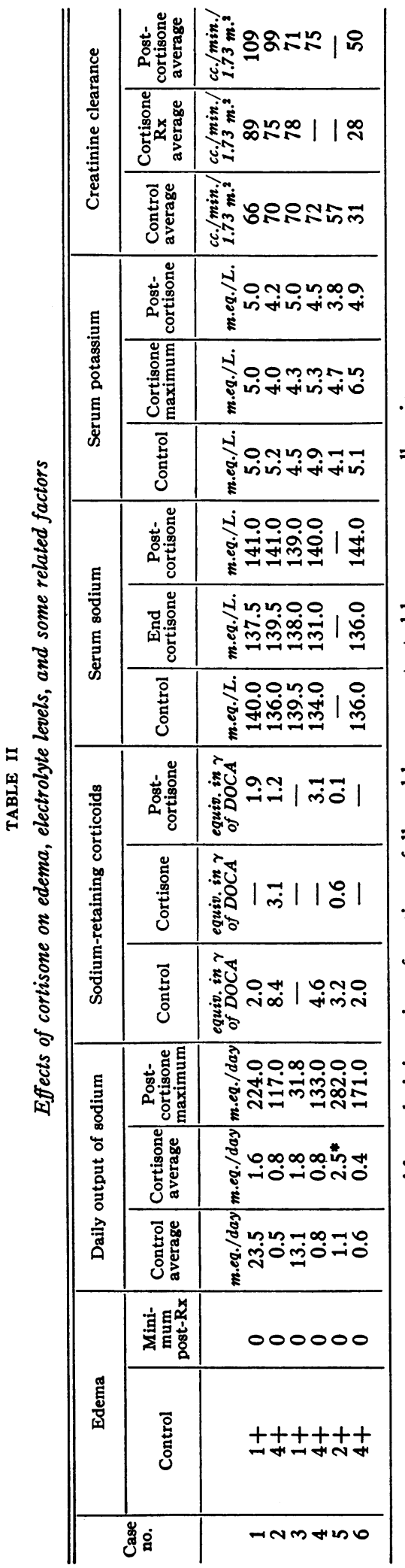

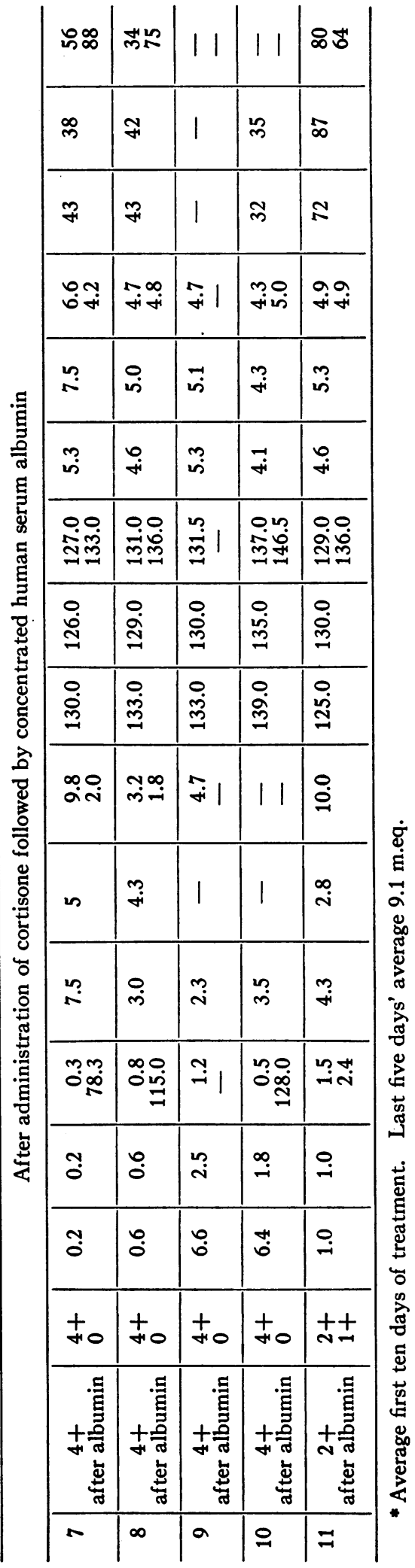


to $43 \mathrm{cc} . / \mathrm{min}$. (average $+19 \mathrm{cc} . / \mathrm{min}$.) in those patients who showed a diuresis, while the change was smaller ( -9 to +13 , average $+4 \mathrm{cc}$. $/ \mathrm{min}$.) in the patients who failed to eliminate edema.

Diuresis was thus generally associated with a higher creatinine clearance, but there was no absolute level of clearance above which diuresis regularly occurred.

Urinary sediment has been examined quantitatively at intervals before, during and after treatment. No significant changes were observed during treatment. In those patients whose proteinuria diminished after treatment and continued at a reduced level, there has been a diminution in the number of all forms of cells and casts in the urine.

Proteinuria was heavier at some time during the administration of cortisone than during the control period in every case, but the increase was often transitory and rarely amounted to more than $3 \mathrm{gm}$. of additional protein per day (Figures $1-3$, Table I). Of the patients who had a diuresis after cortisone, five of the six cases showed a fall in proteinuria beginning on the first day on which no cortisone was given, and continuing during and after diuresis. In case 1 , proteinuria fell to normal levels, while three other patients showed a fall to $200-500 \mathrm{mg}$./day. A difference in handling of injected protein may be noted in Figure 3. During administration of cortisone, a transfusion resulted in proteinuria three times greater than that observed after an equal transfusion after the end of treatment. After a few days or weeks, the proteinuria began to increase, but in two cases there has been a sustained reduction of proteinuria, together with an improved serum protein level and freedom from edema, which has been maintained three and four months after treatment.

Serum protein concentration and albumin concentration were each increased by an average of $0.3 \mathrm{gm} . / 100 \mathrm{cc}$. at the end of cortisone administration (Table I). This increase in the albumin concentration during a period when proteinuria was heavy and when some fluid was being retained strongly suggests an increased production of serum albumin. There was no difference in the average increase of total protein or albumin concentration at the end of cortisone administration when the group who subsequently showed a diuresis or diminution in proteinuria is compared with patients who showed no clinical evidence of improve- ment after treatment. After treatment was discontinued, a large, additional increase in albumin concentration was observed in the patients who showed a diuresis and a reduction in proteinuria. Since the globulin concentration varied only slightly and hematocrit remained quite constant, it seems likely that plasma volume was relatively unaffected, in contrast to its behavior after injections of albumin. Significant increases in serum protein concentration were regularly preceded by some increase in urine volume, and the sharpest rise in serum protein concentration occurred regularly during diuresis. The maximum serum protein and albumin levels were observed from eight to 11 days after the end of cortisone treatment (Figures 1-3). After this point, serum protein and albumin concentrations declined slowly, but have been observed to be maintained for at least several months well above the control observations in two patients, while the patients remained free of edema.

Serum potassium concentration must be carefully watched during cortisone treatment. The administration of cortisone was discontinued in two cases because of a rising serum potassium, which reached $7.5 \mathrm{~m} . e q . / \mathrm{L}$. in one case (Table II). In the other case, cortisone was stopped when the serum potassium reached 6.7 m.eq./L. The concentration declined slowly after cessation of treatment, and rose again in the second patient after administration of $75 \mathrm{mg}$. of cortisone. In a third patient, who had for some weeks deliberately restricted her fluid intake, the serum potassium was 6.5 m.eq./L. before treatment was begun. After three days of forcing fluids, this patient's urine volume rose above $1 \mathrm{~L}$./day, while the serum potassium fell to normal and remained so during treatment.

Cholesterol concentration of serum has not shown any consistent change during treatment, but has fallen slowly in one patient with sustained improvement after treatment.

Total leukocyte count was increased during cortisone treatment in eight of nine cases, and in six of these cases, there was a further rise in the count three to six days after the end of treatment. Total leukocyte counts above 20,000/c.mm. were common in children. Smears showed a preponderance of granulocytes. One patient showed a few myeloblasts in the circulating blood, but bone marrow showed only myeloid hyperplasia. 
Eosinophils were present in unusually large numbers before treatment. The average count before treatment was $460 / \mathrm{c} . \mathrm{mm}$., and counts between 600 and $1,100 / \mathrm{c} . \mathrm{mm}$. were noted in five of the 11 patients. In several patients, a sharp reduction in eosinophils was observed to follow a mild intercurrent infection. The eosinophils usually decreased rapidly in number after administration of cortisone. Dosage of cortisone was increased if the count failed to decline appreciably after two days of treatment at the initial dose. An increase in the number of eosinophils after an initial decrease was noted in only two of the 11 patients.

On cessation of treatment, the count usually remained depressed for one to three days, and then began to increase. It was of interest to note that diuresis began during the phase of increasing eosinophils, suggesting that both events reflected the end of the effects of cortisone. When observations were made for one to three weeks after treatment, the eosinophil count did not return to the very high levels observed in some patients before treatment.

Hematocrit showed no change in the average of the group during administration of cortisone, while individual cases showed changes from +2 to -4 volumes $\%$. Three of the four cases whose hematocrit fell failed to improve after treatment. When diuresis followed cortisone treatment, the average hematocrit remained unchanged, with individual changes from +4 to -3 volumes $\%$.

Erythrocyte sedimentation rate was unaffected by treatment. Even when there was a striking improvement of edema, proteinuria, and serum protein and albumin concentrations, the uncorrected Wintrobe sedimentation rate did not vary more than a few millimeters from its initial very high level. Almost complete packing before centrifugation was noted in nine of the 10 cases in which observations were made, as the sum of the hematocrit and the uncorrected sedimentation rate regularly exceeded $90 \%$ and in one case reached $95 \%$ of the volume of the tube.

Other effects of cortisone (6) were noted in some patients. Mild euphoria and increased appetite were common. Insomnia and mild depression occurred in one patient.

A pink color, due to altered circulation in the hands and face, was apparent in several patients.

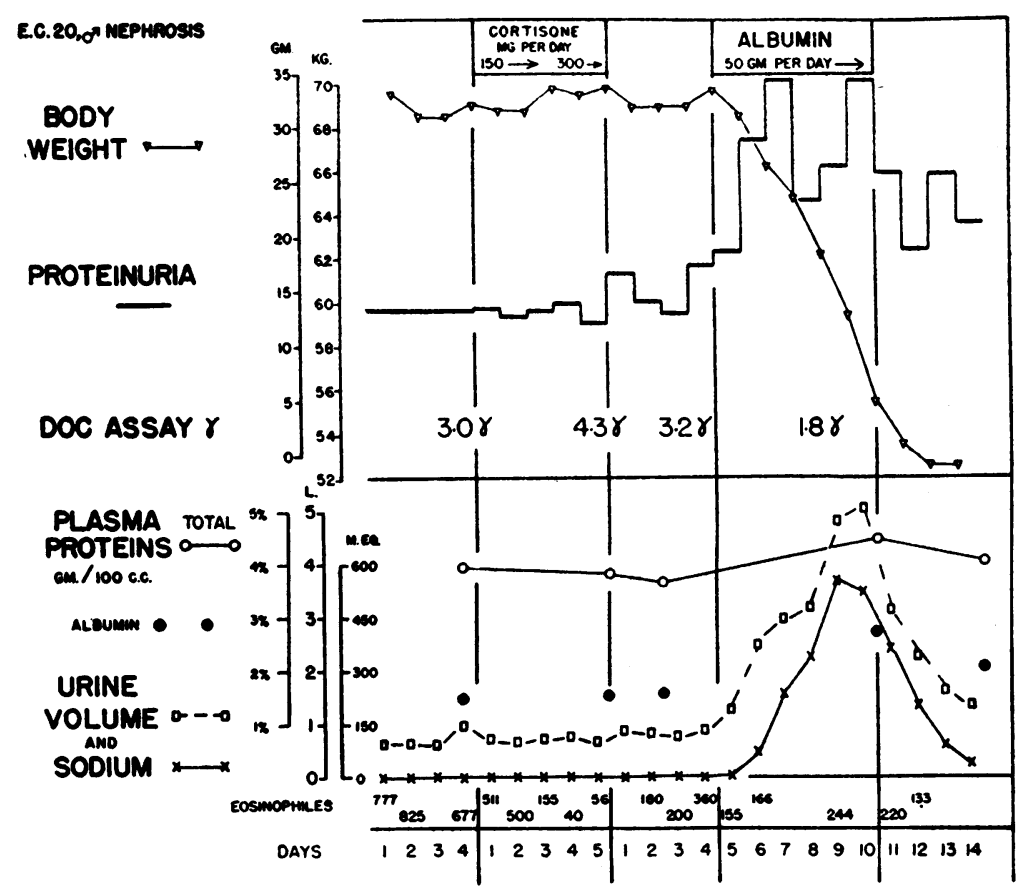

Fig. 4. Failure of a Brief Course of Cortisone to Affect Edema or Level of Sodium-Rrtaining Corticoids, with Subsequent Response to Albumin (CAse 8) 


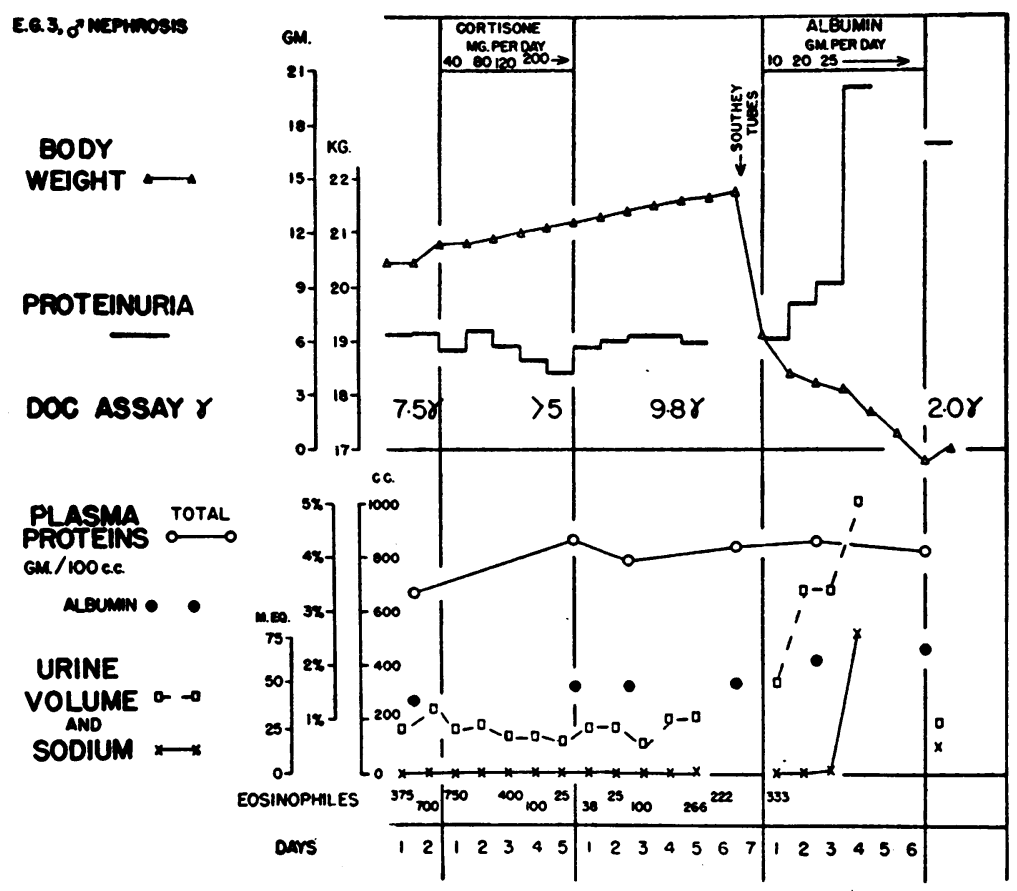

Fig. 5. Failure of a Brief Course of Cortisone to Affect Edema or Level of Sodium-Retaining Corticoids, with Subsequent Response to Albumin (CAse 7)

Note increased serum protein and albumin levels during cortisone administration.

This flush was especially noticeable in contrast to the preceding pallor. The change in color appeared after five to seven days of treatment, and gradually faded when treatment was stopped.

Failure to respond to cortisone treatment was associated with failure to achieve the desired suppression of adrenal activity. In comparing these patients with those who had a diuresis after cortisone (Tables I and II), the only consistent findings in the four patients who failed to respond were: (a) by definition, no significant loss of edema and no increase in urinary volume or sodium after cortisone, $(b)$ little or no diminution in proteinuria after cortisone, and (c) no reduction in the high level of sodium-retaining corticoids in the urine. Although the creatinine clearance had a higher average in the patients who showed a diuresis, no absolute level of clearance divided the patients who improved after treatment from those who did not improve. There was a significantly higher serum sodium concentration at the end of treatment in those patients who responded to cortisone than in the failures, but with some over- lapping of levels in the two groups. No difference in average serum protein or albumin concentration is apparent when the two groups of patients are compared before or at the end of treatment. The serum protein concentration approached normal levels only after diuresis and reduction in proteinuria, and could hardly have affected the result. Nevertheless, it seemed possible that the deficiency of circulating protein might have contributed to the failure of response to cortisone, and that the increase in plasma volume, in glomerular filtration rate, and in serum sodium concentration, which characteristically follow the administration of concentrated human serum albumin, might supply the missing factor.

Effects of subsequent treatment with concentrated human serum albumin were studied in the five cases who failed to eliminate edema after administration of cortisone. Four to seven days elapsed after the end of cortisone treatment before albumin was given. During this time, the eosinophils rose to normal levels, but no appreciable increase in urine volume or sodium was noted. 
In two patients, Southey's tubes and paracentesis were used to reduce the level of edema and to improve an uncomfortably low vital capacity before albumin was administered. Albumin was then given for three to eight days in doses of 10 to 25 gm./day to children, and $50 \mathrm{gm}$./day to adults.

When albumin was administered, four of the five patients responded with complete elimination of edema (Tables I and II). The onset of diuresis was somewhat slower than that previously observed in patients treated with albumin alone (Figures 4 and 5), but the pattern of increased plasma volume and glomerular filtration rate, with early elimination of water and delayed excretion of sodium, was noted as after albumin alone (1). In the fifth case, diuresis was disappointing, no additional sodium appeared in the urine, and some edema remained.

It is of interest that assays of sodium-retaining corticoids in two cases showed a decrease to normal levels during or after a diuresis induced by albumin.

\section{DISCUSSION}

The aim of treatment of nephrosis with cortisone is quite different from the use of cortisone in the rheumatic or "collagen" diseases $(15,16)$. In nephrosis, cortisone appears to aggravate slightly the most obvious renal defects, which are the proteinuria and the retention of sodium and water, although renal function in the excretion of creatinine or inulin is usually improved. The benefits of treatment of nephrosis occur during the period of reduced adrenal function following the abrupt cessation of treatment, a period when the rheumatic or "collagen" diseases may flare up after improvement under cortisone. Continuous administration of cortisone for long-term treatment of nephrosis does not appear to be practical or indicated, in contrast with the successful use of continuous treatment in the suppression of androgen secretion in the adrenogenital syndrome (17).

The observations on these patients support the hypothesis that the adrenal cortex plays a role in the nephrotic syndrome. In most of these patients, an excessive secretion of a sodium-retaining humoral agent with the solubility characteristics of an adrenal cortical steroid has been found. When an increased output of this substance is present, edema seems to be a consistent finding. When this level is depressed after the administration of cortisone, diuresis ensues. Further study of the substances responsible for these findings is indicated before accurate interpretation will be possible.

The changes in proteinuria during and after cortisone treatment indicate that proteinuria in nephrosis can be modified by adrenal steroids, recalling the effects of adrenalectomy and of crystalline adrenal steroids on proteinuria in the rat $(3,4)$. The changes in proteinuria may not coincide with the changes in sodium excretion, however.

These changes after cortisone treatment are similar to those which have been observed to follow certain intercurrent infections in the patient with nephrosis (18). It seems quite likely that such a diuresis may follow decreasing anterior pituitary and adrenal cortical function during convalescence from an acute infection. Similar clinical changes have been observed after administration and withdrawal of pituitary adrenocorticotrophin $(16,19,20)$.

Two further effects are the increased albumin production and the increased creatinine clearance which have occurred during treatment. These evidences of improvement have continued in many patients after the end of treatment.

No ill effect on the renal lesion has followed within a few months after treatment of this group of patients with cortisone. We have not observed a decrease in renal function in any case. There has been some sustained improvement in proteinuria and urinary sediment in two patients who have been followed for three to four months.

The only serious complication of treatment observed thus far is the rising serum potassium observed in two cases. The reasons for this increase appear to be oliguria and reduced renal function, which prevent the kidneys from coping with an increased load of potassium (6-8). There has been no significant decrease in potassium excretion as the serum level rose.

It has been disappointing that a number of the patients have failed to improve after treatment with cortisone. Of the several possible reasons for failure, the only one which is consistently observed is the failure to suppress a high level of urinary corticoids. This suggested that treatment was inadequate in the group which did not im- 
prove after treatment, but other patients have improved after the same or smaller dosage. There has been no clear difference in the type of disease as judged from history, examination of the urinary sediment, or functional studies, since patients who appeared to have a clear background of chronic glomerular nephritis and others without such a background (? lipoid nephrosis) appear both among the failures and in the group who improved after treatment.

Two other abnormalities, a low serum sodium and a low creatinine clearance appear more frequently in the patients who fail to respond to cortisone than in those who show a diuresis. It therefore seemed desirable to test the effect of administration of concentrated human serum albumin to those patients who failed to respond to cortisone, since albumin is known to increase the serum sodium concentration and the renal clearance of creatinine. There was the additional possibility that an increased plasma volume and circulating protein might reduce the abnormal adrenal activity. The observations in Table II indicate that after the administration of albumin, there were large changes in creatinine clearance, in serum sodium concentration, and in the excretion of sodium-retaining corticoids in the direction of normal.

It may be significant that four of these five patients who failed to respond to cortisone have had a complete relief of edema when salt-poor, concentrated human serum albumin was given. It is not apparent from the data which of the several effects of albumin was decisive in the production of a diuresis. It seems likely that cortisone and albumin may affect different mechanisms and may be used together with benefit. It has been shown that replacement of circulating albumin alone fails to cause diuresis in about half of the nephrotic patients (21). The chief abnormality responsible for failure of albumin therapy is presumably an excessive renal tubular reabsorption of sodium and water, which may be reduced after cortisone treatment (1).

It is of interest to compare the changes in serum proteins and in albumin after cortisone with the changes after administration of albumin. If albumin is administered in amounts sufficient to raise the albumin concentration of serum, there is a fall in globulin concentration and in hematocrit as the plasma volume is increased (21). The increase in plasma volume may be smaller if diuresis follows albumin treatment, but it remains clearly demonstrable (1). In contrast, patients who respond to treatment with cortisone show a rise in plasma protein and albumin concentrations without hemodilution as judged from the hematocrit and serum globulin concentration. This smooth readjustment depends on a compensatory elimination of extracellular fluid as the circulating protein is increased. The kidneys appear to be more effective agents in the regulation of plasma protein concentration and of plasma volume after cortisone therapy.

\section{SUM M ARY}

The administration of cortisone ( 0.5 to $2.1 \mathrm{gm}$. total over five to 16 days) to 11 patients with the nephrotic syndrome gave the following results:

(1) During treatment, proteinuria was moderately accentuated, and the excretion of sodium fell to very low levels. Creatinine clearance was usually increased. The serum albumin and protein concentrations rose slightly. In two cases, treatment was stopped because of a rising serum potassium concentration.

(2) After the end of administration of cortisone, the patients followed one of two patterns:

Six patients lost all edema and had a reduction in proteinuria varying from slight to almost complete disappearance of protein from the urine. Serum protein and albumin concentrations were increased to nearly normal levels in two cases. Improvement has been variable in duration from days to months.

Five patients showed no clinical benefit, no increase in sodium excretion, and no decrease in proteinuria.

In comparing the two groups, it was noted that patients who responded with a diuresis showed:

(1) A decrease in the high level of sodium-retaining corticoids in the urine;

(2) A higher average creatinine clearance, which increased further during and after treatment ;

(3) A higher average serum sodium concentration at the end of treatment, rising to normal after diuresis; 
(4) No difference in average total protein or albumin concentrations before or at the end of administration of cortisone, but much greater improvement after subsequent diuresis and lessening of proteinuria.

Four of the five patients who showed no clinical benefit after cortisone, lost their edema when concentrated human serum albumin was given. The administration of albumin was followed by:

(1) A reduction in the high level of sodiumretaining corticoids in the urine;

(2) A further increase in creatinine clearance;

(3) An increase in the serum sodium concentration.

\section{CONCLUSIONS}

These changes in the nephrotic syndrome which occur during and after the administration of cortisone indicate that:

(1) Cortisone induces some improvement in renal function but aggravates some of the findings which have generally been attributed to renal disease.

(2) The improvement which these patients show after the end of treatment coincides with a period of reduced adrenal activity, but may be maintained for a long period.

(3) The adrenal cortex may play an important role in the pathological physiology of the nephrotic syndrome.

(4) The fundamental disorder remains in the kidney, and long-term studies will be necessary to determine the ultimate effect of cortisone on the outcome.

\section{ACKNOWLEDGMENT}

Grateful acknowledgment is made to Miss Nancy Hooper and Miss Esther Sippel for planning and analysis of diets; to physicians of the visiting and resident staffs of Stanford University Hospitals for referral of patients and assistance in their care; to Dr. Chester Keefer, Committee on Investigation of Cortisone, National Academy of Sciences, and to Dr. J. M. Carlisle of Merck and Co. for allocation of cortisone; to Dr. Edward Henderson of Schering Corp. for gifts of desoxycorticosterone; and to the American National Red Cross for normal serum albumin prepared from the blood of voluntary donors and supplied as a part of the National Blood Program. Opinions and conclusions are those of the authors, and do not necessarily reflect the policy of any agency or individual.

\section{BIBLIOGRAPHY}

1. Luetscher, J. A., Jr., Hall, A. D., and Kremer, V. L., Treatment of nephrosis with concentrated human serum albumin. II. Effects on renal function and on excretion of water and some electrolytes. J. Clin. Invest., 1950, 29, 896.

2. Deming, Q. B., and Luetscher, J. A., Jr., Bioassay of desoxycorticosterone-like material in urine. Proc. Soc. Exper. Biol. \& Med., 1950, 73, 171.

3. Addis, T., and Boyd, R. I., Adrenalectomy and renin proteinuria in the rat. Federation Proc., 1949, 8, 1.

4. Addis, T., Marmorston, J., Goodman, H. C., Sellers, A. L., and Smith, M., Effect of adrenalectomy on spontaneous and induced proteinuria in the rat. Proc. Soc. Exper. Biol. \& Med., 1950, 74, 43.

5. Wells, B. B., and Kendall, E. C., The influence of corticosterone and $\mathrm{C}_{17}$ hydroxydehydrocorticosterone (compound E) on somatic growth. Proc. Staff Meet., Mayo Clin., 1940, 15, 324.

6. Thorn, G. W., Forsham, P. H., Bennett, L. L., Roche, M., Reiss, R. S., Slessor, A., Flink, E. B., and Somerville, W., Clinical and metabolic changes in Addison's disease following administration of compound E acetate. Tr. A. Am. Physicians, 1949, 62, 233.

7. Perera, G. A., Pines, K. L., Hamilton, H. B., and Vislocky, K., Clinical and metabolic study of 11dehydro-17-hydroxy-corticosterone acetate (Kendall compound E) in hypertension, Addison's disease, and diabetes mellitus. Am. J. Med., 1949, 7, 56.

8. Sprague, R. G., Power, M. H., Mason, H. L., Albert, A., Mathieson, D. R., Hench, P. S., Kendall, E. C., Slocumb, C. H., and Polley, H. F., Observations on the physiologic effects of cortisone and ACTH in man. Arch. Int. Med., 1950, 85, 199.

9. Forsham, P. H., Thorn, G. W., Prunty, F. T. G., and Hills, A. G., Clinical studies with pituitary adrenocorticotropin. J. Clin. Endocrinol., 1948, 8, 15.

10. Conn, J. W., The mechanism of acclimatization to heat, in: Advances in Internal Medicine, Vol. III, edited by Dock, W., and Snapper, I. Interscience Publishers, New York, 1949, p. 373.

11. McQuarrie, I., Thompson, W. H., and Ziegler, M. R., Effects of posterior pituitary extract on the water and mineral exchanges in edema. J. Pediat., 1936, 8, 277.

12. Randolph, T. G., Blood studies in allergy. I. The direct counting chamber determination of eosinophils by propylene glycol aqueous stains. J. Allergy, 1944, 15, 89.

13. Bonsnes, R. W., and Taussky, H. H., On the colorimetric determination of creatinine by the Jaffe reaction. J. Biol. Chem., 1945, 158, 581.

14. Spencer, A. G., Biological assay of small quantities of desoxycorticosterone acetate. Nature, 1950, 166, 32. 
15. Hench, P. S., Kendall, E. C., Slocumb, C. H., and Polley, H. F., Effects of cortisone acetate and pituitary ACTH on rheumatoid arthritis, rheumatic fever, and certain other conditions. Arch. Int. Med., 1950, 85, 545.

16. Thorn, G. W., Forsham, P. H., Frawley, T. F., Hill, S. R., Jr., Roche, M., Staehelin, D., and Wilson, D. L., The clinical usefulness of ACTH and cortisone. N. England J. Med., 1950, 242, 783 (continued pp. 824, 865).

17. Wilkins, L., Lewis, R. A., Klein, R., and Rosenberg, E., The suppression of androgen secretion by cortisone in a case of congenital adrenal hyperplasia. Bull. Johns Hopkins Hosp., 1950, 86, 249.

18. Janeway, C. A., Moll, G. H., Armstrong, S. H., Jr., Wallace, W. M., Hallman, N., and Lewis, A. B., Diuresis in children with nephrosis. Comparison of response to injection of normal human serum albumin and to infection, particularly measles. Tr. A. Am. Physicians, 1948, 61, 108.

19. Farnsworth, E. B., Studies on influence of adrenocorticotrophin in acute nephritis, in simple nephrosis, and in nephrosis with azotemia, in: Proceedings of the First Clinical ACTH Conference, John R. Mote, Editor. Blakiston Co., Philadelphia, 1950 , p. 297.

20. Farnsworth, E. B., Metabolic changes associated with administration of adrenocorticotropin in the nephrotic syndrome. Proc. Soc. Exper. Biol. \& Med., 1950, 74, 60 .

21. Luetscher, J. A., Jr., Hall, A. D., and Kremer, V. L., Treatment of nephrosis with concentrated human serum albumin. I. Effects on the proteins of body fluids. J. Clin. Invest., 1949, 28, 700.

\section{NOTIFICATION TO SUBSCRIBERS FOR CHANGES IN RATES FOR 1951 NEW AND RENEWAL SUBSCRIPTIONS}

Effective October 1, 1950, new and renewal orders for Volume 30,1951 , will be $\$ 12.00$ (payable in U. S. funds), instead of $\$ 10.00$. Subscriptions are on a January through December or July through June basis.

Special rate for medical students, interns, residents and fellows will be $\$ 6.00$ instead of $\$ 5.00$ as formerly.

Vols. 1-11, inc. (1924-1932)-Special Sales Price, while available, \$25.00. Vol. 12 (1933) through Vol. 29 (1950), \$10.00 a volume.

All single copies from Vol. 1, No. 1 through Vol. 28, No. 6, $\$ 2.00$ each. Vol. 29 (1950), No. 1 , on- $\$ 1.50$ each. 